\title{
Stefan Ciesielski
}

\section{Skrócone postępowanie apelacyjne w kanonicznym procesie o nieważność małżeństwa}

Prawo Kanoniczne : kwartalnik prawno-historyczny 31/1-2, 127-137

1988

Artykuł został zdigitalizowany i opracowany do udostępnienia w internecie przez Muzeum Historii Polski w ramach prac podejmowanych na rzecz zapewnienia otwartego, powszechnego i trwałego dostępu do polskiego dorobku naukowego i kulturalnego. Artykuł jest umieszczony w kolekcji cyfrowej bazhum.muzhp.pl, gromadzącej zawartość polskich czasopism humanistycznych i społecznych.

Tekst jest udostępniony do wykorzystania w ramach dozwolonego użytku. 


\section{SKRÓCONE POSTĘPOWANIE APELACYJNE W KANONICZNYM PROCESIE O NIEWAZNOSC MAEŹENSTWA}

Treśc: Wstęp. - 1. Geneza skórconego postępowania apelacyjnego. - 2. Procedura w trybunale drugiej instancji. - 3. Dekret zatwierdzający wyrok pierwszej instancji. - Zakończenie.

\section{Wstęp}

Nowy Kodeks Prawa Kanonicznego, podobnie jak Kodeks z 1917 r.1, ogólnie stanowi, że postępowanie przed trybunałem apelacyjnym $\mathrm{w}$ zasadzie przebiega zgodnie $\mathrm{z}$ przepisami obowiązującymi $w$ postępowaniu przed trybunałem pierwszej instancji; zaraz po zawiązaniu sporu należy przystapić do dyskusji nad sprawą, a następnie do wydania wyroku, chyba że zaszłaby potrzeba uzupełnienia postępowania dowodowego 2.

Jednakże nowy Kodeks stwarza możliwość, której nie dopuszczał Kodeks poprzedni, przeprowadzenia przed trybunałem apelacyjnym postępowania skróconego, korzystniejszego dla strony powodowej ze względu na możliwość szybkiego zakończenia sprawy. Postępowanie to, proste od strony proceduralnej, kryje w sobie bogatą problematykę, ważną $\mathrm{z}$ punktu widzenia zarówno naukowego jak i praktyki procesowej. Do tej problematyki autor pragnie nawiązać w podjętym rozważaniu.

\section{Geneza skróconego postępowania apelacyjnego}

Ustanowiony przez Benedykta XIV obowiązek obrońcy węzła małżeńskiego apelowania do wyższej instancji od każdego wyroku po raz pierwszy orzekazjącego nieważnosć małżeństwa 3 po Soborze Watykańskim II był przedmiotem ożywionej dyskusji 4 .

1 Codex Iuris Canonici, Pii X Pontificis Maximi iussu digestus, B enedicti Papae XV auctoritate promulgatus (skrót: CICB), kan. 1595 .

2 Kan. 1640.

3 Konst. Dei miseratione, 3 XI 1741, § 8. Fontes, I, n. 318, s. 69.

4 Zob. I. Gord on, De nimia processuum matrimonialium duratione, Periodica de re morali, canonica, liturgica 58 (1969) 641-736. 
W szczególności chođziło o to, czy obrońca węzła w każdym bez wyjątku - przypadku musi apelować i popierać apelację.

Wszyscy zgadzali się z tym, że wyrok po raz pierwszy orzekający nieważność małżeństwa nie może upoważniać strony do zawarcia małżeństwa $z$ innymi osobami; wyrok ten powinien byé potwierdzony przez instancję wyższą. Nie wszyscy jednak uważali za słuszne, aby potwierdzenie wyroku orzekającego nieważność małżeństwa odbywało się w każdym przypadku w drodze zwyczajnego procesu. Zdarzało się bowiem, że obrońca węzła musiał popierać apelację mimo oczywistej nieważności malżeństwa. Jednolita proctdura $\mathrm{w}$ drugiej instancji, wzorowana na procedurze obowiazującej $\mathrm{w}$ instancji pierwszej ${ }^{5}$, powodowała, że strony musiały dlugo czekać, niekiedy' nawet kilka lat, na ostateczne rozstrzygnięcie sprawy. Odbijało się to na dobru duchowym procesujących się stron.

Nic więc dziwnego, że wysunięto postulat, aby kanoniczne postępowanie apelacyjne było zróżnicowane. Dowodzono, że obok zwyczajnego postępowania apelacyjnego powinno mieć miejsce skrócone postępowanie apelacyjne; to drugie powinno być stosowane w razie oczywistej nieważności małzenstwa, stwierdzonej wyrokiem pierwszej instancji.

Zagadnienie reformy procesu małżeńskiego biskupi podjęli na Soborze Watykańskim II. Było ono przedmiotem obrad na sesjach generalnych Soboru $\mathrm{w}$ listopadzie $1964 \mathrm{r}$. Wnioski skierowano do papieża 6; miał je uwzględnić nowy Kodeks Prawa Kanonicznego.

Do sprawy reformy procesu kanonicznego, w tym również procesu małżeńskiego,. wrócono podczas obrad Synodu Biskupów w 1967 r. Ojcowie Synodu domagali się znacznego uproszczenia i przyśpieszenia trybu postępowania sądowego, zwłaszcza $w$ drugiej instancji ?.

Postulaty dotyczące reformy procesu małżeńskiego, zanim znalazły swoje odbicie $\mathrm{w}$ prawie powszechnym Kościoła, były realizowane w sposób eksperymentalny w Kościołach partykularnych. Indult Stolicy Apostolskiej z dnia 28 kwietnia 1970 r. zezwolił na specjalną procedurę $\mathrm{w}$ sprawach małżeńskich Kościolowi w Stanach Zjednoczonych Ameryki Północnej ${ }^{8}$. Podobny indult

5 S. Congr. de Disciplina Sacramentorum, Instr. Provida, 15 VIII 1936, art. 213.

$\checkmark$ Zob. Acta et documenta Concilio Oecumenico Vaticano II apparando, series I, Appendix, vol. II, p. II, Romae 1961, s. 580-593.

7 Zob. A. Przy b 1 a, Prawo kanoniczne $w$ świetle obrad Synodu Biskupów, Ateneum Kapł. 71 (1968) 159-172.

${ }_{8}$ Zob. C. Lefebvre, De procedura in causis matrimonialibus concessa Conferentiae Episcopali U.S.A., Periodica 59 (1970) 563-598; T. Pieronek, Normy postępowania w sprawach matżenskich wydane przez Stolice Apostolska dla diecezji Stanów Zjednoczonych, Prawo Kan. 16 (1973) nr 1-2, s. 177-204. 
otrzymała Konferencja Biskupów Australii dnia 31 sierpnia 1970 r.9 Trybunał Sygnatury Apostolskiej zatwierdził specjalne przepisy proceduralne $w$ sprawach małżeńskich dla Konferencji Biskupów Belgii (10 XI 1970) i Wielkiej Brytanii (2 I 1971) 10 . Kiedy z kolei po podobne indulty zwróciły się Konferencje Biskupów Kanady i Francji, odpowiedzano im, że osobnego indultu nie otrzymaja, natomiast należy oczekiwać specjalnego dokumentu papieskiego $\mathrm{w}$ tej sprawie 11. Tym dokumentem było Motu proprio Causas matrimoniales Pawła VI z dnia 28 marca 1971 r., obowiązujące od 1 paźdiernika 1971 r.12

Motu proprio Causas matrimoniales w nowy sposób uregulowało kilka kwestii dotyczących kanonicznego procesu małżeństwa 13. Jedna $z$ nich jest kwestia procedury apelacyjnej. Postanowienia zawarte $\mathrm{w}$ Motu proprio Causas matrimoniales z niewielkimi zmianami znalazły się w nowym Kodeksie Prawa Kanonicznego.

\section{Procedura $w$ trybunale drugiej instancji}

Cała procedura w skróconym postępowaniu apelacyjnym została wyrażona $w$ nowym Kodeksie prawa Kanonicznego jednym zdaniem: „Jeśli wyrok orzekający nieważność małżeństwa został wydany $w$ sądzie pierwszego stopnia, trybunał apelacyjny, zapoznawszy się z uwagami obroncy węzła i ewentualnymi uwagami stron, swoim dekretem albo potwierdza wyrok, albo sprawe kieruje do zwyczajnego rozpatrzenia w nowej instancji" 14.

A więc skrócone postępowanie apelacyjne może mieć miejsce tylko przed sądem drugiej instancji, jeśli pierwsza instancja wydała wyrok pozytywny czyli orzekający nieważność małzeństwa. Postępowanie to nie może mieć zastosowania przed sądem trzeciej instancji, jeśli wniesiono apelację od wyroku drugiej instancji

9 Communicationes 3 (1971) 103.

10 Zob. W. Góral ski, Uprawnienia udzielone trybunatom kościelnym Belgii oraz Anglii $i$ Walii $w$ zakresie procesu mał̇̇énskiego, Prawo Kan. 17 (1974) nr 3-4, s. 107-115.

11 Communicationes 3 (1971) 103.

12 AAS 63 (1971) 441—446.

${ }_{13}$ Zob. J. Grzy wacz, Zmiany $w$ procesie matżeńskim wprowadzone przez Motu proprio "Causas matrimoniales", Roczniki Teol.-Kan. 19 (1972) z. 5, s. 39 -51; T. P i e ron ek, Reforma kanonicznego procesu małżenskiego według Motu proprio pap. Pawia VI "Causas matrimoniales", Analecta Cracoviensia 4 (1972) 267-314; T. P a w l uk, Reforma kanonicznego procesu malżeńskiego $w$ świetle Motu propric „Causas matrimoniales”, Prawo Kan. 16 (1973) $\mathrm{nr} 3-4$, s. 247-284.

14 Kan. 1682 \& 2: „Si sententia pro matrimonii nullitate prolata sit in primo iudicii gradu, tribunal appellationis, perpensis animadversionibus defensoris vinculi et, si quae sint, etiam partium, suo decreto vel decisionem continenter confirmet vel ad ordinarium examen novi gradus causam admittat". 
po raz pierwszy orzekającego nieważność małżeństwa. Nieważność małżeństwa stwierdzona dopiero $\mathrm{w}$ wyniku apelacji nie jest tak pewna, jak stwierdzona wyrokiem pierwszej instancji, dlatego powinna być potwierdzona $\mathrm{w}$ zwyczajnym postępowaniu apelacyjnym 15.

Postępowanie apelacyjne $w$ trybie skróconym rozpoczyna się po ustaleniu składu trybunału i przyjęciu apelacji - od przekazania akt sprawy obrońcy węzła małżeńskiego drugiej instancji celem sporządzenia uwag (animadversiones). Uwagi obrońcy węzła drugiej instancji mają charakter szczególny: są one pisane nie pro vinculo, lecz pro rei veritate.

Według Kodeksu Prawa Kanonicznego z 1917 r. obrońca węzła małżeńskiego zawsze występował $\mathrm{w}$ obronie węzła 10. Dlątego obrońca zarówno pierwszej jak i drugiej instancji w swoich uwagach przytaczał to wszystko, co mogło przemawiač za ważnością węzła $\mathrm{w}$ konkretnym przypadku. Na odstępstwo od tej zasady zezwoliło Motu proprio Causas matrimoniales Pawła VI, które stanowiło, iż obrońca węzła drugiej instancji ma oświadczyć, utrum contra decisionem latam in primo gradu aliquid opponendum habeat necne $\mathbf{1 7}$.

Nowy Kodeks Prawa Kanonicznego wprawdzie nie powtarza za Motu proprio Causas matrimoniales, iż obrońca węzla sporządza swoje uwagi wedlug własnego uznania czyli pro rei veritate, jednakże przepis kan. $1636 \quad \S 2$ zezwala obroncy trybunału apelacyjnego na zrzeczenie się apelacji 18, co jest równoznaczne z upoważnieniem go do działania pro rei veritate.

Czego powinny dotyczyć uwagi obrońcy węzła drugiej instancji? Można odpowiedzieć ogólnie: tego wszystkiego, co miało wplyw na rozstrzygnięcie sprawy. W szczególności zaś tenże obrońca, przedstawiwszy stan sprawy (facti species), powinien ukazać motywy prawne $w$ odniesieniu do tytułu nieważności danej sprawy i uprawnień trybunału apelacyjnego w sprawach o nieważność małżeństwa, a także motywy faktyczne sprawy, mające wplyw na rozstrzygnięcie, oraz swoje wotum, będące wyrazem jego słusznego stanowiska.

Po złożeniu uwag przez obrońcę. węzła drugiej instancji kolegium sądziewskie może zadecydować o przedlużeniu tych uwag do wglądu stronom bądź ich pelnomocnikom lub adwokatom i zażądać od nich glosów obrończych czyli przeciwuwag (contra-ani-

15 Zob. T. P awluk, Kanoniczny proces matżenski, Warszawa 1973,. s. 171.

16 Zab. CICB, kan. 1968 n. 3.

17 Norma VIII \& 2.

$18 \mathrm{Kan} .1636$ § 2: „Si appellatio proposita sit a vinculi defensore vel a promotore iustitiae, renuntiatio fieri potest, nisi lex aliter caveat, a vinculi defensore vel promotore justitiae tribunalis appellationis". 
madversiones): Przepis kodeksowy nie nakazuje zwracania się po te głosy obrończe, lecz tylko wspomina o możliwości ich przedłożenia: si quae sint. Podobną dyspozycję zawierało Motu proprio Causas matrimonales 19. Niekiedy bowiem sprawy są tak oczywiste, np. z tytułu niemocy płciowej, choroby psychicznej czy przymusu i bojaźni, że zwracanie się do stron po replikę byłoby bezużyteczne i przyczyniłoby się tylko do zwłoki w zakończeniu sprawy. Pominięcie przeciwuwag stron $w$ takich przypadkach nie byłoby sprzeczne $z$ prawem do obrony 20 .

Gdyby trybunał apelacyjny zadecydowal o zwróceniu się do stron po glosy obrończe, należałoby wyznaczyć odpowiedni termin na ich złożenie. Nieprzedłożenie głosów obrończych $w$ wyznaczonym terminie jest równoznaczne ze zrezygnowaniem z przedłożenia tych glosów. Na przeciwuwagi, przedłożone przez strony lub ich patronów, obrońca węzła nie musi odpowiadać. Prawo bowiem nie wspomina o dawnym przywileju obrońcy, dzięki któremu mógł on zawsze przemawiać jako ostatni 21.

Po rozważeniu uwag obrońcy węzła małżeńskiego i ewentualnych przeciwuwag stron lub ich patronów trybunal apelacyjny wydaje dekret, którym albo zatwierdza wyrok pierwszej instancji, alibo przekazuje sprawę do zwyczajnego rozpatrzenia sądowi drugiej instancji.

\section{Dekret zatwierdzający wyrok pierwszej instancji}

Pozornie wydaje się, że nowe prawo procesowe zezwala na wydanie dekretu sądowego, zatwierdzającego wyrok pierwszej instancji, już po rozważeniu samych uwag obrońcy węzła i ewentualnych przeciwuwag stron lub ich patronów: perpensis animadversionibus defensoris vinculi et, si quae sint, etiam partium. W praktyce tak jednak nie jest. Uwagi obrońcy węzła i stron byłyby niezrozumiałe, gdyby trybunał apelacyjny nie przestudiowal wyroku pierwszej instancji pod względem zarówno merytorycznym jak i formalnym 22 . Przestudiowanie wyroku zakłada skonfrontowanie go $z$ aktami pierwszej instancji. Oznacza to, że sędziowie trybunału apelacyjnego zanim wydadzą dekret powinni zbadać nie tylko uwagi obrońcy węzła i stron, lecz także wyrok

19 Norma VIII \& 2: „... Contra quas animadversiones collegium, si opportunum censuerüt, partium earumve patronorum animadversiones exquirat".

${ }_{20}$ T. P a w l u k, Reforma kanonicznego procesu matżenskiego $w$ swietle Motu proprio "Causas matrimoniales", s. 272.

21 Zob. CICB, kan. 1969 n. 2-3.

${ }_{22}$ Motu proprio Causas matrimoniales postanawiało: Visa sententia et perpensis animadversionibus defensoris vinculi necnon, si exquisitae et datae fuerint, partium earumve patronorum..." 
pierwszej instancji, a nawet akta tej instancji 23. Takie stanowisko zajmowała Rota Rzymska interpretując Motu proprio Causas matrimoniales z 1971 r.24

Trzeba tu jednak zauważyć, że reforma postępowania apelacyjnego nie osiągnęłaby celu, gdyby sędziowie trybunału apelacyjnego przez wiele miesięcy analizowali akta sprawy przed ustosunkowaniem się do wyroku pierwszej instancji. Dobrze umotywowane uwagi obrońcy węzła, a także wyrok jasno ukazujący stan prawny i stan faktyczny, powinny studiowanie akt istotnie skrócić, ograniczając je do niezbędnego wglądu.

Dekret zatwierdzający, wyrok pierwszej instancji rie ma charakteru czysto administracyjnego, lecz jest sądowy. Nie chodzi tu o dekret nakazujący wykonanie wyroku pierwszej instancji, lecz o orzeczenie rozstrzygające. Dekret sądowy, jeśli nie ma charakteru zwykłego zarządzania, powinien być umotywowany 25.

Problem motywacji dekretu sądowego, zatwierdzajacego wyrok pierwszej instancji, poczactkowo nie był rozstrzygany $w$ jednakowy sposób. Wynikało to $z$ braku jednoznacznego tekstu ustawy. Po wprowadzeniu na mocy Motu proprio Causas matrimonia- les skróconego postępowania $\mathrm{w}$ trybunale drugiej instancji nie brakło procesualistów, nawet w Rocie Rzymskiej, którzy twierdzili, że wspomniany dekret drugiej instancji do swej ważności nie musi być umotywowany, ponieważ nie ma on charakteru rozstrzygającego (decretum decisorium), lecz tylko wykonawczy (decretum exsecutorium) ${ }^{26}$. Niektórzy kanoniści nie byli zdecydowani, jakie zająć stanowisko $\mathrm{w}$ tej sprawie ${ }^{27}$. W większości jednak dekretów rotalnych podkreślano potrzebę motywowania pod względem prawnym i faktycznym dekretów zarówno ratyfikujących wyrok pierwszej instancji, jak i odsyłających sprawę do rozpatrzenia $w$ drodze zwyczajnego procesu. Tego rodzaju stanowisko rotalne było uzasadnione tym, że nie chodzi tu o zwykły dekret, lecz o rozstrzygnięcie mające znaczenie wyroku definitywnego, wywołujące te same skutki prawne, co $i$ wyrok 28 .

Aby nie było wątpliwości natury prawnej, zwrócono się do Papieskiej Komisji Interpretacji Dekretów Soboru Watykańskie-

23 A. Stankiew ic.z, Niektóre zagadnienia dotyczace skróconego postepowania apelacyjnego $w$ swietle najnowszych decyzji Roty Rzym$s k i e j$, Prawo Kan. 17 (1974) nr 1-2, s. 125-128.

24 Zob. tamże, s. 128, przypis 11 i 12.

25 Zob. kan. 1617.

26 Zo:b. I. M. P in to, De nullitate decreti ratihabitionis ob non expressa motiva vel ob appellationis concursum ad normam M.P. "Causas matrimoniales", Periodica 62 (1973) 551-562; A. Stanki.ewicz, jw. s. $133-134$.

27 A. Colagiovanni, De innovatione processus matrimonialis in iure et in iurisprudentia S.R. Rotae, Neapoli 1973, s. 50.

${ }^{28}$ Zob. A. Stankiewicz, jw. s. 129 . 
go II z prośbą o autentyczne wyjaśnienie normy VIII $\S 3$, znajdującej się $\mathrm{W}$ Motu proprio Causas matrimoniales. Komisja ta w dniu 14 lutego 1974 r. orzekła, że dekrety trybunalu apelacyjnego, wydawane po myśli wspomnianej normy, muszą być umotywowane 29 ; nie orzekła jednak, że motywy są potrzebne do ważności dekretu 30. Dlatego do wspomnianej Komisji skierowano nowe pytanie, aby dowiedzieć się, pod jaka sankcją należy dekret motywować: nieważności dekretu, czy tylko jego legalności. Komisja stanęła na stanowisku, że motywy są konieczne do ważności dekretu ${ }^{31}$.

Nowy Kodeks Prawa Kanonicznego rówwież stanął na stanowisku, że dekret trybunału apelacyjnego powinien być umotywowany. Stanowisko to jednak wynika $\mathrm{z}$ ogólnej zasady, zawartej $\mathrm{w}$ przepisie kan. 1617. Przepis ten stanowi, że dekrety sędziego, które ñie są zwylkłymi zarządzeniami, nie mają mocy prawnej, jeżeli przynajmniej w sposób sumaryczny nie podają motywów Iub nie odsyłają do motywów podanych $w$ innym akcie 32.

Motu proprio Causas matrimoniales określając czynność trybunału apelacyjnego $\mathrm{w}$ postępowaniu skróconym stanowiło: Collegium suo decreto vel decisionem primi gradus ratam habet, vel ad ordinarium examen secundi gradus causam admittit 33. W nowym Kodeksie tę samą treść wyrażono nieco inaczej: Tribunal appellationis... suo decreto vel decisionem continenter confirmet vel ad ordinarium examen novi gradus causam admittat ${ }^{34}$. A więc trybunał apelacyjny nie ratyfikuje wyroku pierwszej instancji, lecz go po prostu zatwierdza. Prawodawcy kodeksowemu chodziło o to, by uniknąć wszelkich spekulacji na temat charakteru dekretu instancji apelacyjnej, jakie miały miejsce po ukazaniu się Motu proprio Causas matrimoniales ${ }^{35}$.

Trybunał apelacyjny zatwierdzając wyrok pierwszej instancji powinien go zatwierdzić w całości; nie jest dopuszczalne zatwier-

29 AAS 66 (1974) 463.

30 Zob. I. M. Pint o, De exprimendis rationibus in ratihabitionis decreto, Periodica 64 (1975) 195-204.

s1 Zapytano: Utrum motiva decidendi in decretis, de quibus in interpretatione authentica diei 14 februarii 1974, praebenda sint sub sanctione nullitatis ipsorum decretorum an tantum ad legitimitatem. Odpowiedź Komisji z dnia 1 VII 1976 r. brzmiała: Affirmative ad primum, negative ad secundum. AAS 68 (1976) 635.

${ }^{32}$ Kan. 1617: „Ceterae iudicis pronuntiationes, praeter sententiam, sunt decreta, quae si mere ordinatonia non sint, vim non habent, nisi saltem summarie motiva exprimant, vel ad motiva in alio actu expressa remittant".

3 Norma VirI § 3.

${ }^{34}$ Kan. $1682 \S 2$.

35 Zob. A. Stankiewicz, jw. s. $133-134$. 
dzenie tylko części wyroku. Wskazują na to słowa: decisionem continenter confirmet $\mathbf{3 6}$.

Czy trybunal drugiej instancji może swoim dekretem zatwierdzić wyrok pierwszej instancji orzekający nieważność malżeństwa także $w$ razie wniesienia apelacji przez stronę pozwaną? Czy w takim przypadiku trybunal apelacyjny nie jest obowiązany skierować sprawę do rozpatrzenia i rozstrzygnięcia w drodze zwyczajnego procesu?

Swojego czasu, po ukazaniu się Motu proprio Causas matrimoniales, był to problem głośny. Wielu audytorów Roty Rzymskiej stanęło na stanowisku, że przy zbiegu apelacji obrońcy węzła małżeńskiego $z$ apelacja strony pozwanej należy sprawę odesłać ad ordinarium tramitem iuris, czyli do rozpatrzenia $w$ trybie zwyczajnego postępowania. Takie stanowisko zarysowało się już w dekrecie rotalnym $\mathrm{z}$ dnia 3 marca 1972 r., c. Agustoni. W dekrecie tym sformułowano zasadę: Si autem pars conventa pro suo gravamine recurrat, tunc... eligenda est via examinis ordinarii causae 37. Takie stanowisko zostało szeroko uzasadnione w dekrecie rotalnym z dnia 22 marca 1972 r., c. Canals 38.

Jednakze wielu audytorów Roty Rzymskiej zajęlo odmienne stanowisko, twierdząc, że apelacja strony pozwanej nie przeszkadza w stosowaniu skróconego postępowania apelacyjnego, gdyż strona, która czuje się pokrzywdzona, może ođwołać się do trzeciej instancji 39. A nawet stwierdzano wprost, że takiej stronie już nie przysluguje prawo do apelacji; apelacja bowiem co do swej istoty wywodzi się z prawa natury, lecz co do formy pochodzi z pozytywnego prawa ludzkiego, które niekiedy może ograniczyć prawo do apelacji 40.

Ogólnie rzecz oceniając można powiedzieć, że jurysprudencja rotalna skłaniała się raczej do opinii, która opowiadała się za stosowaniem skróconego posteppowania apelacyjnego także w ra-

36 Wprawdzie w polskim tłumaczeniu nowego Kodeksu Prawa Kanonicznego słowo continenter w kan. 1682 \& 2 przetłumaczono „bez zwłoki", jednakże wydaje się, że chodzi tu o przysłbwek od contineo (= utrzymuje w całości).

37 A. Stankiewicz, jw. s. 136, przypis 36 .

$38 \mathrm{~W}$ dekrecie tym stwierdzono, że: 1) skrócone postępowanie apelacyjne, przewiidziane $w$ Motu propnio Causas matrimoniales, może mieć miejsce, jeśli apelację wnosi obrońca węzła, nie zaś strona pozwana; 2) ustawodawca nie pozbawil strony pozwanej prawa do obrony własnego stanowiska, wobec tego nie można stosowwak postępowania skróconego, jeśli od wyroku pierwszej instancji apeluje, obok obrońcy węzła, także strona poizwana; 3) postęporwanie skrócone jest czymś wyjątkowym w stosunku do procesu zwyczajnego, dlatego przepis o stosowaniu postępowania skróconego nie może być szeroko tłumaczony. Zob. A. Stankjewicz, jw. s. 137-138, przypis 39 i 40 .

39 Zoib. A. Stankiewicz, jw. s. 139, przypis 42 .

40 Zob. tamże, s. 140, przyplis 46. 
zie apelacji strony pozwanej. Zdawano jednak sobie sprawę, że żadna $\mathrm{z}$ dwóch opinii ratalnych nie dysponuje ostatecznymi argumentami 41.

Zdaje się, że prawodawca kodeksowy był świadom kontrowersji co do stosowania procesu skróconego $\mathrm{w}$ trybunale drugiej instancji $w$ razie wniesienia apelacji przez stronę pozwaną. Kodeks bowiem stanowi, że wyrok orzekający nieważność małżeństwa należy przesłać do trybunału apelacyjnego wraz $z$ ewentualnymi apelacjami: una cum appellationibus, si quae sint ${ }^{42}$. Oznacza to, że skrócone postępowanie apelacyjne może odbyć się nawet w razie apelacji strony pozwanej.

Wspomnieliśmy już, że dekret trybunału apelacyjnego może też nakazać rozpatrzenie sprawy $\mathrm{w}$ drodze zwyczajnego procesu. Rzecz jasna, że muszą istnieć ku temu racje. Racje te należy wyliczyć $\mathrm{w}$ dekrecie skierowującym sprawę do rozpatrzenia $\mathrm{w}$ trybie zwyczajnym. W okresie poprzedzającym ukazanie się nowego Kodeksu Prawa Kanonicznego tylko nieliczni żądali, aby dekrety odsyłające sprawę na drogę zwyczajnego procesu były umotywowane 43. Dzisiaj, w swietle kan. 1617, tego rodzaju dekrety również powinny być umotywowane.

W. razie skierowania sprawy na drogę zwyczajnego procesu sprawę rozpatruje trybunal apelacyjny drugiego stopnia. Przepis kodeksowy $\mathrm{w}$ tej sprawie jest niejasny, gdyź słanowi, że sprawę rozpatruje trybunał nowego stopnia 44. Nie chodzi tu jednak o trybunal trzeciej instancji, lecz instancji drugiej, która jest instancją nową $w$ stosunku do instancji pierwszej. Zresztą Motu proprio Causas matrimoniales wyraźnie stanowiło, że trybunał apelacyjny ad ordinarium examen secundi gradus causam admittit ${ }^{45}$.

\section{Zakończenie}

Do istotnych zmian, jakie $\mathrm{w}$ odniesieniu do apelacji wprowadzilo nowe prawo procesowe, należy zaliczyć uproszczenie samej procedury apelacyjnej i możliwość zatwierdzenia wyroku pier-

41 Zob. tamże, s. 141, przypis 50; O. Di Jorio, Concursus appellationis defensoris vinculi et partis gravatae. Adnotatio ad M.P. "Causas matrimoniales", Periodica 62 (1973) 393-401.

42 Kan. $1682 \S 1$.

43 A. Stankiewicz, jw. s. $135-136$.

44 Kan. 1682 \& 2: ,Si sententia pro matrimonii nullitate prolata sit in primo iudicii gradu, tribunal appellationis... ad ordinarium examen novi gradus causam admittat".

45 Norma VIII \& 3 . 
wszej instancji orzekającego nieważność małżeństwa dekretem trybunału apelacyjnego. Daje to szansę szybkiego zakończenia sprawy o nieważność małżeństwa, zgodnie $z$ duchowym interesem stron. Wyrok pierwszej instancji w wyniku potwierdzenia go dekretem instancji apelacyjnej staje się prawomocny, a strony, skoro tyllzo dekret zostanie im podany do wiadomości, mogą zawrzeć nowe związki małżeńskie, zgodnie z kan. 1684 § 1 .

Tego rodzaju reforma procesowa, usankcjonюwana w kanonach 1682-1684 nowego Kodeksu Prawa Kanonicznego, dokonała się na gruncie przygotowanym przez Sobór Watykański II, a następnie przez posoborowe prawo kanoniczne; przy czym na ostateczny ksztalt reformy zasadniczy wplyw miala ustawa procesowa Causas matrimoniales Pawła VI oraz dyskusja procesualistów podjęta przy okazji interpretowania tej ustawy.

Uproszczonej procedurze apelacyjnej nie można zarzucać, że ogranicza uprawnienie strony pozwanej do obrony, płynące $z$ prawa naturalnego. Owszem, apelacja wypływa z prawa natury; prawo naturalne domaga się, aby każdemu pokrzywdzonemu dać możność obrony. Jednkże tylko apelacja jako środek obrony przed krzywdzącym i niesprawiedliwym wyrokiem, a nie forma apelacji, jest oparta na prawie natury. Dlatego skrócenie postępowania apelacyjnego przez nowe prawo procesowe nie sprzeciwia się słuszności naturalnej.

Poprzednio rozbudowana forma apelacji, rozciągająca się na lata i na instancje coraz to wyższe, utrudniała zakończenie sprawy. Rozbudowana forma apelacji sprawiała, że adwokaci niekiedy nawet celowo zachowywali nowe dowody i argumenty, aby je przedłożyć dopiero w instancjach wyższych, kiedy to łatwiej mogli wywołać efekty pozytywne dla strony. Dzisiaj, dzięki rozbudowanemu postępowaniu dowodowemu i wysokim kwalifkacjom sędziów kościelnych, w wielu przypadkach można sprawę o nieważność małżeństwa wystarczająco wyświetlić w sądzie pierwszej instancji.

Możliwość przeprowadzenia postępowania apelacyjnego $\mathrm{w}$ trybie skróconym jest uzależniona od rzetelnego wyświetlenia sprawy $w$ trybunale pierwszej instancji. Dobrze przeprowadzona instrukcja procesu przez sąd pierwszej instancji jest najlepszą gwarancją sprawiedliwego wyrcku, a jednocześnie - $w$ razie orzeczenia przez tenże sąd nieważności małżeństwa - jest podstawą do szybkiego zakończenia sprawy $\mathrm{w}$ instancji apelacyjnej. Stwierdzone niedokładności $w$ postępowaniu dowodowym przed sądem pierwszej instancji sprawią, że trybunal drugiej instancji skieruje sprawę do rozpatrzenia apelacyjnego $w$ trybunale zwyczajnym. 
De procedura summaria apud tribunal secundae instantiae in causis nullitatis matrimonii

Hoc in articulo disceptatur de praescripto can. 1682, § 2. Selectae sunt tres quaestiones: 1) de genesi procedurae summariae apud tribunal secundae instantiae in causis nullitatis matrimonii, 2) de ipsa procedura necnon 3) de tribunalis appellationis decreto confirmanti sententiam pro nullitate matrimonili in primo iudicii gradu prolatam. 